\title{
Growth performance of fingerlings of Clarias gariepinus fed fermented seed of Senna obtusifolia (Linn)
}

${ }^{1}$ Onimisi, H. U.*, ${ }^{2}$ Oniye, S. J., ${ }^{2}$ Balogun, J. K., and ${ }^{1}$ Bolorunduro, P. I.

${ }^{1}$ National Agricultural Extension and Research Liaison Services

${ }^{2}$ Department of Biological Sciences

Ahmadu Bello University. Zaria

Abstract Corresponding author: onimisihas@yahoo.com (08023635058)

The effects of replacing soybean meal with graded levels of fermented Senna obtusifolia seed meals (SOSM) on the growth performance of Clarias gariepinus were investigated. Five isonitrogenous (42\% crude protein) and isocaloric (25.7\% NFE) diets were formulated in which fermented replaced soybean meal (SBM) at 0\% (SOSM0), 25\% (SOSM25), 50\% (SOSM50), 75\% (SOSM75) and 100\% (SOSM100) inclusion levels and a commercial feed $(\mathrm{CmF})$ as the second control. Three hundred and sixty (360) fingerlings of (Clarias gariepinus) mean weight (2.85 $\pm 0.01 \mathrm{~g}$ ) were stocked at (20) fish per tank volume in triplicate groups per treatment and fed 3\% body weight twice a day of the experimental diets for 180 days. The feeding rate was adjusted after weighing. The water qualities were within range recommended for Clarias gariepinus. There were no significant differences $(p>0.05)$ in growth performance and nutrient utilization between the control groups and those fed the fermented SOSM diets at 25\%. The commercial, $0 \%$ and 25\% groups had the highest mean weight gain (279 to $280 \mathrm{~g})$, significantly $(P<0.05)$ superior to the groups that received the, $50 \%, 75 \%$ while the group that received $100 \%$ SOSM diet had the poorest mean weight gain (132.72g). Feed conversion ratios (FCR) of all treatments ranged from (1.75 to 2.18). These values increased slightly by increasing levels of fermented SOSM from 50 to $100 \%$. The best $F C R, 1.75 \pm 0.02$, recorded for fish fed 25\% fermented SOSM indicated a superior level of utilization of the SOSM diet by the fish. There was no significant difference $(P>0.05)$ in the protein intake among the group of fish fed 0 and $25 \%$, but significant difference $(P<0.05)$ occur in fish fed 50, 75 and 100\% fermented SOSM respectively. Protein efficiency ratio $(P E R)$ exhibited significant differences $(P<0.05)$ in all treatments except in the control diets that were not statistically different $(P>0.05)$ from the fish fed the $25 \%$ fermented SOSM. The $P E R$ values increased among the experimental fish with respect to the quantity of total feed intake. There were no significant differences $(P>0.05)$ in apparent net protein utilization (ANPU) among treatments $\mathrm{CmF}, 0 \%$ and 25\%. The ANPU was highest in fish fed $0 \%$ fermented SOSM (91.6 \pm 0.04$)$ while fish fed 75 and $100 \%$ fermented SOSM in diets were $71.4 \pm 0.02$ and $73.4 \pm 0.03$ were the least. There was a significant $(P<0.05)$ difference in the effect of the inclusion levels of fermented (SOSM) on final body carcass composition among treatments. This study showed that soybean meal can be substituted with fermented Senna obtusifolia seed meal up to $25 \%$ level in Clarias gariepinus diets without any negative effects on the growth and feed efficiency.

Keywords: Growth; fermented Senna obtusifolia (Linn); Clarias gariepinus fingerlings

\section{Introduction}

Profitable fish culture requires unfailing supply of formulated fish feed of low cost using the cheapest sources of proteins. To maintain the profitability of raising Clarias gariepinus, cutting down the production costs is necessary, mainly through feeding, which has been acknowledged generally as the major cost incurred during the production cycle (Eyo, 2003; Jamu and Ayinla, 2003; Akinrotimi et al., 2007). Gabriel et al. (2007) reported that feed 


\section{Performance of fingerlings of Clarias gariepinus fed fermented seed of Senna obtusifolia (Linn)}

alone in fish farming accounted for between $60-70 \%$ of the running expense in the operation of a fish farm enterprise. Reduction in feeding cost can be obtained by optimizing feeding strategies, nutrient levels in diets, and by using plant sources as substitutes for fish oil and fish meal (Martinez-Llorens et al., 2009). Plant feedstuffs have received most attention in recent years; however, due to amino acid imbalances, presence of anti-nutritional compounds, low palatability and poor digestibility, a high level of replacement of fish meal with plant feedstuffs is generally not well accepted by fish (Belgin et al., 2009). Some plant ingredients have been studied in the production of Clarias gariepinus, among which jack bean and soybean meal, are widely used because of their high protein (40-60\%) content, low cost and relative availability. Soybean meal, being the most nutritive, has been used as the major protein source in many fish diets; partial or total replacement of dietary fish meal by soybean meal had been accomplished with clarias and other catfish species (Soltan et al., 2001; Fagbenro and Davies, 2002; Wilson, et al., 2004, Abdelhamid et al., 2006; Magdy, 2006). Senna obtusifolia is an annual plant, a serious weed in many places and a competitive shrub that grows in the tropics (Ingweye et al., 2010). The plant grows to a height of about $1.5-2.5 \mathrm{~m}$ tall and $1 \mathrm{~m}$ wide. The pod is $10-15 \mathrm{~cm}$ long, $3-5 \mathrm{~mm}$ wide, slender and sickle shaped. The plant prefers well drained fertile soil. The proximate composition of the seeds shows a high dry matter $(95.50 \%)$, crude protein $(29.54 \%)$, crude fibre $(10.18 \%)$, while the leaves contains dry matter $(92.40 \%)$, crude protein $(27.4 \%)$, crude fibre $(16.8 \%)$, ether extract $(3.8 \%)$, nitrogen free extract $(36.8 \%)$ with high concentrations of anti-nutrients which can be detoxified through processing
(Ingweye et al., 2010 and Ayssiwede, et al., 2011). There is dearth of information on the use of fermented Senna obtusifolia seed meal in fish and animal feed formulation; hence the aim of this study was to evaluate the effect of partial and complete replacement of soyabean meal with graded levels of fermented Senna obtusifolia seed meal on growth performance of Clarias gariepinus.

\section{Materials and methods Collection and processing of Senna obtusifolia seeds}

The seeds of Senna obtusifolia were handpicked in Shika Zaria, Kaduna State. The seeds were soaked in water in a 1:6 (seeds: water) i.e. $1 \mathrm{~kg} / 6$ lit ratio for $12 \mathrm{~h}$, drained and soaked seeds were allowed to ferment for four days (Udensi et al., 2006). The fermented seeds were air dried for two days, and were ground into fine powder, and analyzed for proximate composition, amino acids, mineral elements and antinutritional compounds.

\section{Experimental fish}

Three hundred and sixty (360) fingerlings of Clarias gariepinus with mean initial weight $(2.85 \pm 0.01 \mathrm{~g})$ were stocked at twenty fish per tank in three replicates per treatment after acclimatization.

\section{Feed formulation and pellet preparation}

The experimental diets contained fish meal (FM), soybean meal (SBM), yellow maize meal (YMM), groundnut cake meal (GNCM) and fermented Senna obtusifolia seed meal (SOSM). All ingredients were ground into a fine powder using a hammer mill and sieved to pass through a $0.25-\mathrm{mm}$ sieve. FM, SBM, GNCM and YMM were obtained from commercial suppliers. Prior to feed formulation, proximate compositions of these ingredients were determined (Table 1). On the basis of the 


\section{Onimisi, Oniye, Balogun and Bolorunduro}

proximate composition of the ingredients, five isonitrogenous diets $(42 \% \mathrm{CP})$ and Isocaloric (gross energy $2777 \mathrm{kcal} \mathrm{kg}^{-1}$ ) was prepared where the fermented Senna obtusifolia seed meal (SOSM) replaced soybean meal (SBM) at 0\%, 25\%, 50\%,
$75 \%$, and $100 \%$. While $0 \%$ (SBM0) and commercial pelleted feed served as the control diets (Table 2). Diet samples were subjected to proximate analysis as described (A.O.A.C.2000) and presented in Table 3.

Table 1: Proximate and Energy Composition of Ingredients used in the Experimental diets

\begin{tabular}{|c|c|c|c|c|c|c|c|c|}
\hline Ingredients & & Moist\% & СР\% & EE\% & CF\% & ASH\% & NFE $\%$ & GE \\
\hline Fish meal & & 9.78 & 72 & 7.92 & - & 11.03 & 4.89 & 2980 \\
\hline Soya meal & & 7.92 & 44 & 2.6 & 7.8 & 5.6 & 32 & 2400 \\
\hline Yellow corn & & 9.13 & 8.9 & 3.48 & 11.6 & 3.81 & 63.08 & 3447 \\
\hline GNC meal & & 9.09 & 43 & 5.2 & 6.0 & 5.8 & 30.91 & 2400 \\
\hline $\begin{array}{l}\text { Fermented } \\
\text { obtusifolia }\end{array}$ & Senna & 6.54 & 32.11 & 7.71 & 4.3 & 5.14 & 44.2 & 3226 \\
\hline
\end{tabular}

Table 2: Gross Composition of the Experimental diets for Clarias gariepinus fingerling

\begin{tabular}{|c|c|c|c|c|c|c|}
\hline Ingredients & & $0 \%$ & $25 \%$ & $50 \%$ & $75 \%$ & $100 \%$ \\
\hline Maize & & 23 & 21.0 & 19. & 16 & 13 \\
\hline $\begin{array}{l}\text { Fermented } \\
\text { obtusifolia }\end{array}$ & Senna & - & 8.75 & 17.5 & 26.25 & 35 \\
\hline Ground nut cake & & 15 & 17.5 & 20.5 & 23 & 27 \\
\hline Soya bean meal & & 35 & 26.25 & 17.5 & 8.75 & - \\
\hline Fish meal & & 24 & 24 & 24 & 24 & 24 \\
\hline Palm oil & & 2 & 2 & 1.5 & 1.5 & 2 \\
\hline Vitamins & & 0.25 & 0.25 & 0.25 & 0.25 & 0.25 \\
\hline Salt & & 0.2 & 0.2 & 0.2 & 0.2 & 0.2 \\
\hline Lysine & & 0.25 & 0.25 & 0.25 & 0.25 & 0.25 \\
\hline Methionine & & 0.25 & 0.25 & 0.25 & 0.25 & 0.25 \\
\hline Total & & 100 & 100 & 100 & 100 & 100 \\
\hline
\end{tabular}

Table: 3 proximate compositions of experimental diets Clarias gariepinus fingerling

\begin{tabular}{lllllll}
\hline Composition & CF & $\mathbf{0 \%}$ & $\mathbf{2 5 \%}$ & $\mathbf{5 0 \%}$ & $\mathbf{7 5 \%}$ & $\mathbf{1 0 0 \%}$ \\
\hline Crude protein & 42.34 & 42.35 & 42.28 & 42.23 & 42.22 & 42.24 \\
Moisture & 7.86 & 7.38 & 7.49 & 7.90 & 7.38 & 7.48 \\
Crude lipid & 14.69 & 11.47 & 11.46 & 11.69 & 11.84 & 11.79 \\
Crude fibre & 2.8 & 4.91 & 4.62 & 4.59 & 5.32 & 5.33 \\
Ash & 6.7 & 8.21 & 8.30 & 8.46 & 8.14 & 8.18 \\
NFE & 25.7 & 25.68 & 25.85 & 25.03 & 25.10 & 24.98 \\
Dry matter & 92.23 & 92.62 & 92.51 & 92.00 & 91.62 & 92.12 \\
\hline
\end{tabular}

CF: Commercial feed, NFE: Nitrogen free extract

\section{Experimental procedures}

The experimental system consisted of 18 units cylindrical black plastic tanks of 380L capacity, 50-cm diameter and 50cmdepth each in a complete randomized design. Water was supplied to each tank at a rate of $1-\mathrm{L} \mathrm{min}^{-1}$ from a 2000-L header GP tank. Fish were fed the experimental diet at $3 \%$ body weight twice a day for 180 days.
Feeding quantity was adjusted after every weighing fortnightly for growth and survival records (mean body weight, mean standard length and mortality).Water $\mathrm{pH}$ and temperature was taken daily (8.00$9.00 \mathrm{~h})$ using combined $\mathrm{pH}$ and thermometer model pH-009(111), while the Dissolved oxygen (DO) was determined using the DO meter model DO-510. 
Growth and feed utilization parameters

The data collected was analyzed for the following

Mean body weight gain $(\mathrm{MWG})=\mathrm{W}_{2}-\mathrm{W}_{1}$

Where $\mathrm{W}_{1}=$ initial body weight $\mathrm{W}_{2}=$ Final body weight Specific Growth Rate(SGR) = $100\left(\right.$ Ln W $\left.\mathrm{W}_{2}-\mathrm{Ln} \mathrm{W}_{1}\right) / \mathrm{T}$--------------(Kaushik,1998)

Where $\mathrm{W}_{1}=$ initial body weight $\mathrm{W}_{2}=$ Final body weight $\mathrm{Ln}=$ Natural $\log$

Feed conversion Ratio $(\mathrm{FCR})=$ weight of feed fed/weight gain by fish x 100----------(Adikwu, 2003)

Protein Efficiency Ratio (PER) = weight gain/weight of protein fed

Apparent Net protein utilization $(\mathrm{NPU})=$ fish protein gained $(\mathrm{g}) /$ protein consumed (g) X100 (Jackson et al., 1982). Carcass proximate composition of fish before and after the feeding trial were determined as described by AOAC (2000)

\section{Statistical analysis}

Data collected were subjected to one way analysis of variance (ANOVA) using
General Linear Model (GLM) procedure of SAS (SAS, 2004). Duncan Multiple Range F-test (DMRT) was used to separate means. Value of $\mathrm{P}<0.05$ was considered significant.

\section{Results \\ Growth performance and feed utilisation of clarias gariepinus}

Figure1 showed that there was a slow growth of fish in all treatments during the first two weeks of culture, particularly in the groups fed $50 \%, 75 \%$ and $100 \%$ after which, a significant growth was evident in the fish fed the commercial feeds (CF), treatments 0 and $25 \%$.

There was a fairly uniform pattern of growth for fish fed diets $\mathrm{CmF}, 0 \%$ and $25 \%$ from the fourth week. Fish fed $\mathrm{CmF}$ increased in weight above the other treatments between weeks four to the end of the feeding period. Fish fed diet containing $50-100 \%$ SOSM lagged behind those of fish fed diets $\mathrm{CmF}, 0 \%$ and $25 \%$ after the fourth week.

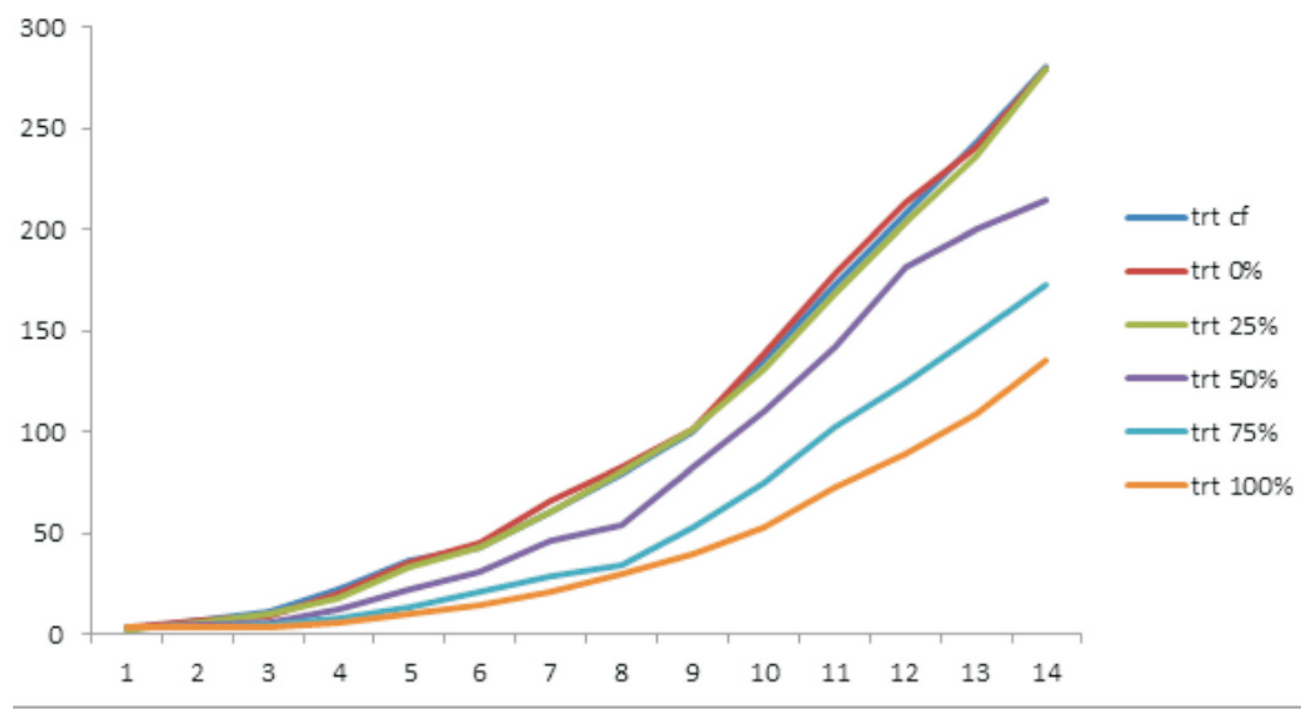

Fig.1: Biweekly growth pattern of Clarias gariepinus fed graded levels of fermented Senna obtusifolia seed meal 


\section{Onimisi, Oniye, Balogun and Bolorunduro}

Table 5 showed that nutrient utilization was not affected $(p \geq 0.05)$ in the control and that of the fish fed the $25 \%$ inclusion of FSOSM. The commercial, $0 \%$ and $25 \%$ FSOSM groups had the highest mean weight gain (279 and $280 \mathrm{~g}$ ) significantly $(\mathrm{P}<0.05)$ higher than the fish that received $50 \%$ and $75 \%$ FSOSM, while the fish that received 100\% FSOSM inclusion had the poorest mean weight gain $(132.72 \mathrm{~g})$. Feed conversion ratios (FCR) ranged from 1.79 to 2.18 , these values increased as the inclusion of FSOSM increased from 50 to $100 \%$. The best FCR (1.79 \pm 0.02$)$ was recorded for fish fed 25\% FSOSM. Protein intake among the fish fed 0 and $25 \%$ FSOSM was not affected ( $\mathrm{p} \geq 0.05$ ), fish fed 50, 75 and 100\% FSOSM, however, had different $(\mathrm{p}<0.05)$ protein intake levels. Protein efficiency ratio (PER) exhibited significant differences $(\mathrm{P}<0.05)$ in all treatments except in the control and fish fed the 25\% SOSM. Apparent net protein utilization (ANPU) among treatments CF, $0 \%$ and $25 \%$ was not affected $(\mathrm{p} \geq 0.05)$. The ANPU was highest in fish fed $0 \%$ fermented SOSM (91.6 \pm 0.04$)$ while fish fed 75 and $100 \%$ FSOSM had the least $(71.4 \pm 0.02$ and $73.4 \pm 0.03)$ respectively. Higher survival rates were found in the group of fish fed 0, 25, 50 and commercial feed, but lower survival occured in fish fed 75 and $100 \%$ fermented SOSM (Table 5).

Table 5: Growth performance and nutrient utilization of Clarias gariepinus fed graded levels of fermented SOSM

\begin{tabular}{|c|c|c|c|c|c|c|c|c|}
\hline \multicolumn{9}{|c|}{ Levels of inclusion of fermented Senna obtusifolia seed meal (\%) } \\
\hline Indices & \multicolumn{2}{|c|}{$\mathrm{CmF}$} & $0 \%$ & $25 \%$ & $50 \%$ & $75 \%$ & $100 \%$ & SEM \\
\hline Mean initial weight & 2.8 & & $2.85^{\mathrm{a}}$ & $2.86^{\mathrm{a}}$ & $2.84^{\mathrm{a}}$ & $2.87^{\mathrm{a}}$ & $2.85^{\mathrm{a}}$ & \pm 0.01 \\
\hline Mean final weight & 28 & $36^{\mathrm{a}}$ & $280.08^{\mathrm{a}}$ & $279.62^{\mathrm{a}}$ & $218.47^{\mathrm{b}}$ & $173.48^{\mathrm{c}}$ & $135.81^{\mathrm{d}}$ & \pm 13.91 \\
\hline Mean weight gain & 27 & $92^{\mathrm{a}}$ & $277.23^{\mathrm{a}}$ & $276.76^{\mathrm{a}}$ & $215.6^{\mathrm{b}}$ & $170.60^{c}$ & $135.81^{\mathrm{d}}$ & \pm 13.91 \\
\hline Specific growth rate & 1.1 & & $1.12^{\mathrm{a}}$ & $1.13^{\mathrm{a}}$ & $1.06^{\mathrm{b}}$ & $0.97^{\mathrm{c}}$ & $0.92^{\mathrm{d}}$ & \pm 0.02 \\
\hline FCR & 1.8 & & $1.79^{\mathrm{b}}$ & $1.81^{\mathrm{b}}$ & $2.09^{\mathrm{a}}$ & $2.18^{\mathrm{a}}$ & $2.11^{\mathrm{a}}$ & \pm 0.04 \\
\hline PER & 1.3 & & $1.38^{\mathrm{a}}$ & $1.36^{\mathrm{a}}$ & $1.15^{\mathrm{b}}$ & $1.09^{c}$ & $1.12^{\mathrm{bc}}$ & \pm 0.03 \\
\hline ANPU & 91 & & $91.83^{\mathrm{a}}$ & $91.63^{\mathrm{a}}$ & $76.35^{\mathrm{b}}$ & $71.43^{c}$ & $71.70^{\mathrm{c}}$ & \pm 2.29 \\
\hline Survival rate & 98 & & $97.33^{\mathrm{a}}$ & $95.33^{\mathrm{b}}$ & $87.33^{c}$ & $82.67^{\mathrm{d}}$ & $80.67^{d}$ & \pm 1.72 \\
\hline Mean feed intake & 48 & $80^{\mathrm{a}}$ & $483.58^{b}$ & $484.48^{b}$ & $446.69^{c}$ & $371.57^{\mathrm{d}}$ & $279.64^{\mathrm{e}}$ & \pm 18.62 \\
\hline Protein Intake & 20 & $38^{\mathrm{a}}$ & $203.10^{\mathrm{b}}$ & $203.48^{\mathrm{b}}$ & $187.61^{\mathrm{c}}$ & $156.07^{\mathrm{c}}$ & $117.45^{\mathrm{e}}$ & \pm 7.82 \\
\hline \multicolumn{9}{|c|}{ Figures on the same row having the same superscript are not significantly different $(\mathrm{p}>0.05)$} \\
\hline \multicolumn{9}{|c|}{$\begin{array}{l}\text { FCR: Feed conversion ratio, PER: Protein efficiency ratio, ANPU: Apparent net protein efficiency } \\
\text { utilisation }\end{array}$} \\
\hline \multicolumn{9}{|c|}{$\begin{array}{l}\text { Table 6: Carcass compositions of Clarias gariepinus fed graded levels of Fermented Senna } \\
\text { obtusifolia seed meal }\end{array}$} \\
\hline \multicolumn{9}{|c|}{ Levels of inclusion of fermented Senna obtusifolia seed meal (\%) } \\
\hline Indices & & $\mathrm{CmF}$ & $0 \%$ & $25 \%$ & $50 \%$ & $75 \%$ & $100 \%$ & SEM \\
\hline Crude protein & $27^{\mathrm{e}}$ & $67.71^{\mathrm{a}}$ & $67.41^{\mathrm{ab}}$ & $67.21^{\mathrm{b}}$ & $66.25^{\mathrm{c}}$ & $65.52^{\mathrm{d}}$ & $65.18^{\mathrm{d}}$ & \pm 0.33 \\
\hline Lipids & & $7.81^{\mathrm{a}}$ & $7.81^{\mathrm{a}}$ & $7.68^{\mathrm{b}}$ & $6.46^{\mathrm{c}}$ & $5.98^{d}$ & $5.84^{\mathrm{d}}$ & \pm 0.22 \\
\hline Moisture & & $6.51^{\mathrm{e}}$ & $6.34^{\mathrm{e}}$ & $6.34^{\mathrm{e}}$ & $8.76^{c}$ & $9.85^{b}$ & $10.48^{\mathrm{a}}$ & \pm 0.36 \\
\hline Ash & & $9.51^{\mathrm{b}}$ & $9.67^{b}$ & $9.63^{b}$ & $12.35^{\mathrm{a}}$ & $12.48^{\mathrm{a}}$ & $12.50^{\mathrm{a}}$ & \pm 0.35 \\
\hline NFE & $91^{\mathrm{a}}$ & $8.88^{\mathrm{d}}$ & $9.13^{c}$ & $9.24^{b}$ & $6.77^{\mathrm{e}}$ & $6.41^{\mathrm{f}}$ & $6.08^{\mathrm{g}}$ & \pm 0.63 \\
\hline
\end{tabular}




\section{Performance of fingerlings of Clarias gariepinus fed fermented seed of Senna obtusifolia (Linn)}

\section{Carcass composition}

The proximate carcass composition of experimental fish fed graded levels of FSOSM was determined at the beginning and at the end of the experiment. The initial carcass compositions of fish were 7.41, $63.27,5.25,8.64$, and $14.91 \%$ for moisture, protein, lipid, ash and NFE, respectively (Table 6). The FSOSM affected $(p<0.05)$ final body carcass composition among treatments.

\section{Discussion}

Water quality parameters such as temperature, $\mathrm{pH}$ and dissolved oxygen in this study are within the recommended limits for warm-water fishes (Boyd and Gross, 2000; Ajani, 2006). The fingerlings consumed all the diets but feed intake was higher in groups that received diets with lowest levels of fermented Senna obtusifolia seed meal (FSOSM). The lower feed intake in the groups fed the 50\%, 75\% and $100 \%$ diets could be due to poor quality resulting from residual anti-nutritional factors such as tannin and non-starch polysaccharide (NSP) (Alegbeleye et al., 2011). Soluble NSP has been reported to be deleterious to the growth performance of young fish (Leenhouwers et al., 2009).

The enhanced growth performance observed in the fish with lower inclusion of FSOSM could be as a result of the synergetic effect of combining two biological compounds having a single and superior effect than when applied individually. This observation is in agreement with suggestions by previous authors that combined protein source is better than single protein source for fish diets (Ugwumba et al., 2001; Sogbesan et al., 2005; Sogbesan and Ugwumba, 2006a). (Fagbenro et al., 2010) assert that there could be a physiological mechanism in fish that could compensate for the presence of lower inclusion level of anti-nutrients hence their negative effect may not be felt, but at higher level of inclusion, when the limit might have been exceeded, then the negative effect of these anti-nutrients will be pronounced as clearly depicted in this study. The lowered growth performance of fish fed higher level of FSOSM may be attributed to reduced bioavailability of minerals, impaired protein digestibility caused by formation of phytic acid-protein complexes and depressed absorption of nutrients (Francis et al., 2001). The inability of Clarias gariepinus to effectively utilize high dietary inclusion level of FSOSM beyond $25 \%$ could be associated with low concentration of the enzyme cellulase which is absent in most piscivores such as Malapterurus electricus, Gymnarchus niloticus, Parachanna obscura but available in Tilapia species (Fagbenro et al., 2005). In Clarias gariepinus which is an omnivore but with a higher tendency towards being a canivore, the enzyme cellulase is anticipated in the gastro intestinal tract in appreciable quantity to effect digestion. But opposite appears to be the case in this study. The utilization of $25 \%$ inclusion of FSOSM in the diets by Clarias gariepinus is in agreement with finding of Olukunle and Agboola (2005); and Aminsah et al. (2009). The best feed conversion ratio (FCR), $1.75 \pm$ 0.02 , recorded for fish at $25 \%$ inclusion of FSOSM indicated a superior level of utilization of the FSOSM diet by the fish and this obviously accounted for better growth performance of $C$. gariepinus fed $25 \%$ inclusion of FSOSM diet among other diets. Adikwu (2003) reported that the lower the FCR the better the feed utilization by the fish. The higher PER value obtained in the control and $25 \%$ inclusion of FSOSM treatments points to high utilization of inherent nutrients in the diet at this level in 


\section{Onimisi, Oniye, Balogun and Bolorunduro}

comparison to higher inclusion levels (> $25 \%$ and above ). This agrees with the observation by Adejumo (2005) who reported high PER value at $20 \%$ inclusion level when maize was replaced with fermented millet. The improved ANPU in fish fed $25 \%$ inclusion of FSOSM compared to other treatments in this study, might be due to the fact that, protein deposition is significantly influenced by the ratio of FSOSM and soya bean meal in the diets. The carcass composition of the experimental fishes showed that all the fishes fed the experimental diets had higher carcass protein, lipid and ash contents but lower nitrogen free extract than the initial fish sample. This may be implied that there was protein synthesis and increased tissue production in C. gariepinus and that fish growth was not due to the increase in weight alone (Koven et al., 2001; Fountolaki et al., 2003). The moderately high level of carcass fat in fish fed the control and diets with $25 \%$ inclusion of FSOSM indicated an enhanced production of lipids in the fish (Udo et al., 2012). Increase in lipids has been associated with increase efficiency of metabolism. Similar result was also observed in gilthead bream fingerlings (Fountolaki et al., 2003). Fish fed diets higher inclusion of FSOSM had higher body moisture content and low lipid. The decrease in lipid content is probably due to poor feed intake which resulted in starvation and in turn led to mobilization of body lipid reserves to meet energy requirements for vital body functions. Similar results have been reported in Clarias lazera (Hogendoorn, 1983) and rainbow trout (Reinitz, 1983).

\section{Conclusion}

The study showed that soybean meal can be substituted with fermented Senna obtusifolia seed meal up to $25 \%$ level in Clarias gariepinus diets without any negative effects on the growth and feed efficiency.

\section{References}

Abdelhamid, A. M., Salem, M. F. I. and Khalafalla, M. M. E. 2006. Substitution of soybean meal by water hyacinth hay in diets of Nile tilapia (Oreochromis niloticus). The $2^{\text {nd }}$ Inter. $\mathrm{S} \mathrm{c} \mathrm{i} \quad \mathrm{C}$ o n.$\quad F$ o r Environment "Recent Environment Problems and Social Shrement", 2830 March, South V a 11 e y University. Pp: 114- 126 50. In: C.B. Cowey, C.Y. Cho (eds.). Nutritional Strategies a $n$ d Aquaculture Waste. Univ.of Guelph, Guelph.

Adeniji, C. A., Fakoya, K. A. and Omamohwo, V. R. 2007. Partial replacement of soybean $\mathrm{c}$ a $\mathrm{k}$ e with Amaranthus spinosus leaf meal in the diet of Nile tilapia, Oreochromis niloticus. Pak.J. Sci. Ind. Res., 50: 335-338.

Adewolu, M. A. and Adamson, A. A. 2011. Amaranthus spinosus leaf meal as potentialdietary protein source in the practical diets for Clarias gariepinus (Burchell, 1822) fingerlings. Int. Journal of Zoology. Res. 7:128-37.

Adikwu, I. A. 2003. A Review of Aquaculture Nutrition in Aquaculture Development in Nigeria. In: Proceeding of National Workshop on Fish Feed Development and Feeding Practices in Aquaculture. Fis heries Society of Nigeria/NIFFR/FAO-NSPFS, New Bussa, Sept. 15-19, pp. 34-42.

Amisah, S. and Oteng, M. A. 2009. Growth performance of the African catfish, Clarias gariepinus, fed varying inclusion levels of 


\section{Performance of fingerlings of Clarias gariepinus fed fermented seed of Senna obtusifolia (Linn)}

Leucaena leucocephala leaf meal. Journal of Applied Science. Environment and maternal offspring transfer of gossypol in rainbow trout (Oncorhynchus mykiss) fed diets containing cottonseed meal.Journal of Animal Science. 79, 1533-1539.

A.O.A.C. 2000. Association of Official Analytical Chemists Official Methods of Analysis. $17^{\text {th }}$ e dition, Washington, D.C. USA.

Ayssiwede, S. B., Zanmenou, J. C., Issa, Y., Hane, M. B., Dieng, A., Chrysostome, C.A. A. M., Huninato, M. R., Hornick, J. L., and Missohou, A. 2011. Nutrient Composition of $\mathrm{S}$ o $\mathrm{m}$ e Unconventional and Local Feed Resources Available in Senegal and recoverable in Indigenous Chickens or Animal Feeding. Pakistan Journal of Nutrition 10 (8): 707- 717.

Barrows, F. T. and Hardy, R.W. 2000. In "Encyclopedia of Aquaculture" (R. R. Stickney, ed.), pp. 354-359. John Wiley \& Sons, New York.

Belgin, H. Nejdet, G. and Smith, S. 2009. Replacement of fishmeal by yeast (Saccharomyces cerevisiae) Effect on Digestibility and Blood Parameters for Gilt head Sea bream (Sparus auratus) Journal Of Animal Science Veterinary Advances Vol. 8:12 pp 2557- 2561.

Boyd, C. E. and Gross, A. 2000. Water use and conservation for inland aquaculture ponds. Fisheries Management and Ecol., 7: 55-63

Eyo, A. A. 2003. Fundamental of fish nutrition and diet development: An overview. In Fish Feed Development and feeding Practices in Aquaculture, Eyo,A.A. (Ed.).
FISON, Lagos Nigeria.

Fagbenro, O. A. and Adebayo, O. T. 2005. A review of the animal and aquafeed in Nigeria. In: Moehl. J. \&Halwart M. (eds.), A synthesis of the formulated animal and aqua feedindustry in Sub-Saharan Africa, CIFA Occasional paper no. 26, FAO Rome, pp. 25-36.

Fagbenro, O. A. and Davies, S. J. 2002. Use of oilseed meals as fishmeal replacer in tilapia diets. Proceeding of the fifth international symposium on tilapia aquaculture. Rio de Janeiro- RJ, $\quad$ B r a z i 1 1:145-153.

Faturoti, E. O. and Akinbote, R. E. 1986. Growth response and Nutrients Utilization in Oreochromis niloticus Fed varying levels of dietary cassava peel. Nigerian Journal of Applied Fisheries and Hydrobiology. 1:47-50

Francis, G., Makkar, H. P. S. and Becker, K. 2001. Anti-nutritional factors present in plant- derived alternate fish feed ingredients and their effects in fish. Aquaculture 199: 197-227.

Gabriel, U. U., Akinrotimi, O. A., Bekibele, D. O. Onunkwo, D. N. and Anyanwu, P. E. 2007, Locally Produced Fish Feed, Potentials for Aquaculture Development In Sub- Saharan African Journal of Agricultural Research 297: 287-295.

Han, Y. W. 1988. Removal of phytic acid from soybean and cottonseed $\mathrm{m}$ e a $1 \mathrm{~s}$. Journal of Agriculture and Food Chemistry 3.,6 (6):1181-1183

Hossain, M. A. and Jauncey, K. 1989. Studies on the protein, energy and amino acid digestibility of 
fish meal, mustard oil cake, linseed and sesame meal for common carp (Cyprinus carpio L . ). Aqua, 83: 59- 72.

Ingweye, J. N., Kalio, G. A., Ubua, J. A., and Umorem, E. P. 2010 Nutritional Evaluation of Wild Sickle Pod (Senna obtusifolia) Seeds from Obanliku South-Eastern Nigeria.American Journal of Food Technology 5(1):1-12

Jabeen, S, Salim M, Akhtar, P. 2004. Study on feed conversion ratio of major carp(Cirrhinus mrigala) fingerlings fed on cotton seed meal, fish meal and barley. Pakistan Vet. J., 24(1): $\quad$ 42-46.

Konyene, J. E., Sogbesan, A. O. and Ugwumba, O. A. 2006. Nutritive value and utilization of $\mathrm{w}$ a $\mathrm{t}$ e $\mathrm{r}$ hyacinthEicohhornia crasspes) meal as protein supplementin diet of Clarias gariepinus fingerlings. Afr. Sci., 7: York.127-133.

Leenhouwers, J. F., Veld, M., Vereth, J. A. J. and Schrama, J. W. 2009. Digesta characteristics of performance of African catfish (Clarias gariepinus) fed cereal grains that differ in viscosity. Aquaculture, 264:330-341.

Lie, O., Lied, E. and Lamberston, G. 1989. Haematological values and fatty acid composition of erythrocyte phospholipids in cod (Gadus morhua) fed at different w a t e r t e m p e r a t u r e s. Aquaculture, 79: 137-144.

Magdy, M. G. 2006. Partial and complete replacement of fish meal by broad bean meal in feeds for Nile tilapia, Oreochromis niloticus, L., fry. Aquaculture Research, 37:985.

Martınez-Llorens, S.,Vidal, A. T., Garcia, I. J., Torres, M.P. and
Cerda, M.J. 2009. Optimum dietary soybean meal level for maximizing growth and nutrient utilization of on growing gilthead sea bream (Sparusaurata), Aquaculture nutrition. 15: 320-328.

Pandian, T. J. and Vivekanandan, E. 1985. Energetics of feeding and d i g e s t i o n. I n : F i s h Energetics:New Perspective (Tytler, P.and Calow, P. eds), Croom-Helm, Sydney, Australia, p. 99-124.

Pusztai, A. 1989. Biological effects of dietary lectins. J.Huisman, T.F.B.Poel \& I.E.Liener, R e c e $n \mathrm{t}$ Advances of Research in Antinutritional Factors in Legumeseeds: Animal Nutrition, Feed Technology, Analytical M e thods. Wa gen ingen (Netherlands), Pudoc, pp.17-29

Queensland Government 2006. Facts, natural resources and water pest series- Sickle pods: Sickle pod/arsenic weed (S. obtusifolia), foetid senna ( $S$. tora) and hairy $\mathrm{s}$ e $\mathrm{n} \mathrm{n}$ a $(S . h i r u s t a$ http//wwwnqccs.com.au/library/we eds/sicklepod.pdf

Shabbir S, Salim M, Rashid, M. 2003. Study on the feed conversion ratio ( F C R ) in m a jor c a r p (Cirrhinus mrigala) fed on sunflower meal, wheat bran and maize gluten (30\%). Pakistan Vet.J., 23(1):1-3.

Sogbesan, O. A. and Ugwumba, A. A. A. 2008. Nutritional Values of Some Non-Conventional A nimal Protein Feedstuffs Used as Fishmeal Supplement in Aquaculture Practices in Nigeria Turkish Journal of fisheries and aquaculture sciences 8, 150-164.

Sogbesan, O. A., Ajuonu, N. D., 
Performance of fingerlings of Clarias gariepinus fed fermented seed of Senna obtusifolia (Linn)

Ugwumba, A. A. A. and Madu, C. T. 2005. Cost benefits of $\mathrm{maggot}$ meal as supplemented feed in the diets of Heterobranchus longifilis $\mathrm{x}$ Clarias gariepinus (PiscesClariidae) hybrid fingerlings in outdoor concrete tanks. Journal of Industrialand Scientific Research 3 (2), 51-55.

Sogbesan, O. A., Ugwumba, A. A. A. and Madu, C. T. 2006. Nutritive potential and utilization of garden snail (Limicolaria aurora) meat in the diet of Clarias gariepinus fingerlings .African Journal of Biotechnology 5 (20), 1999-2003.

Soltan, M. A., Ibrahim, M. K., Fatma, A. and FathElbab, A. F. 2001. Effect $\begin{array}{llllll}\text { of partial and } & t & o & t & a & 1\end{array}$ replacement of fishmeal by soybean meal on growth and proximate analysis of Nile tilapia. Egyptian Journal. Nutrition and Feed, (4 special issues 799: 812. sources in practical fish feeds. In Cowey C.B, Mackie A.M., Bell J.G. (ed.) Academic Press, London, pp. 119145.
Tibbetts, S. M., Milley, J. E. and Lall, S. P. 2006. Apparent protein and energy digestibility of common and alternative feed ingredients by Atlantic cod, Gadus morhua ( L i n n a e u s, 1758 ). Aquaculture 261:1314-1327.To a practical diet for juvenile Penaeus monodon Fabricius. Fisheries Resources Journal Philippines. 8:667.

Udensi, E. A. and Okonkwo, K. A. 2006. Effects of fermentation and g e r m in a tion o n the physicochemical properties of Mucuna cochinchnensis protein isolates. African Journal of Bio technology. Vol 5(10) 896-900

Ugwumba, A. A. A., Ugwumba, A. O. and Okunola, A. O. 2001. Utilization of L i v maggot a $\mathrm{g}$ supplementary feed on the growth of Clarias gariepinus (Burchell) fingerlings. Nigerian Journal of Science 35 (1)1-7.

Received: $25^{\text {th }}$ August, 2016 Accepted: $12^{\text {th }}$ March, 2017 